\title{
Genetic variation underlying resistance to infectious hematopoietic necrosis virus in a steelhead trout (Oncorhynchus mykiss) population
}

\author{
Marine S. O. Brieuc ${ }^{1,2, *}$, Maureen K. Purcell ${ }^{2}$, Alexander D. Palmer ${ }^{1,3}$, Kerry A. Naish $^{1}$ \\ ${ }^{1}$ School of Aquatic and Fishery Sciences, University of Washington, Seattle 98195, WA, USA \\ ${ }^{2}$ Western Fisheries Research Center, US Geological Survey, Seattle 98115, WA, USA \\ ${ }^{3}$ Present address: School of Molecular and Cellular Biology, University of Illinois at Urbana-Champaign, IL 61801, USA
}

\begin{abstract}
Understanding the mechanisms of host resistance to pathogens will allow insights into the response of wild populations to the emergence of new pathogens. Infectious hematopoietic necrosis virus (IHNV) is endemic to the Pacific Northwest and infectious to Pacific salmon and trout (Oncorhynchus spp.). Emergence of the M genogroup of IHNV in steelhead trout O. mykiss in the coastal streams of Washington State, between 2007 and 2011, was geographically heterogeneous. Differences in host resistance due to genetic change were hypothesized to be a factor influencing the IHNV emergence patterns. For example, juvenile steelhead trout losses at the Quinault National Fish Hatchery (QNFH) were much lower than those at a nearby facility that cultures a stock originally derived from the same source population. Using a classical quantitative genetic approach, we determined the potential for the QNFH steelhead trout population to respond to selection caused by the pathogen, by estimating the heritability for 2 traits indicative of IHNV resistance, mortality $\left(h^{2}=0.377(0.226-0.550)\right)$ and days to death $\left(h^{2}=0.093(0.018-0.203)\right)$. These results confirm that there is a genetic basis for resistance and that this population has the potential to adapt to IHNV. Additionally, genetic correlation between days to death and fish length suggests a correlated response in these traits to selection. Reduction of genetic variation, as well as the presence or absence of resistant alleles, could affect the ability of populations to adapt to the pathogen. Identification of the genetic basis for IHNV resistance could allow the assessment of the susceptibility of other steelhead populations.
\end{abstract}

KEY WORDS: Infectious hematopoietic necrosis virus $\cdot$ IHNV $\cdot$ Oncorhynchus mykiss $\cdot$ Disease resistance $\cdot$ Evolution $\cdot$ Fish disease $\cdot$ Heritability

\section{INTRODUCTION}

Understanding the mechanisms of host resistance to pathogens will allow insights into their role in the emergence and transmission of such pathogens across a landscape. Infectious hematopoietic necrosis virus (IHNV) is a single-stranded negative-sense RNA rhabdovirus (Wolf 1988) that is endemic to the

*Corresponding author: mbrieuc@uw.edu
Pacific Northwest and infectious to Pacific salmon and trout (Oncorhynchus spp.), as well as Atlantic salmon Salmo salar. There are 5 phylogenetic genogroups of IHNV worldwide, and 3 of these genogroups ( $U, M$, and $L$ ) are endemic to North America (Kurath 2012). The U genogroup viruses are found in the northern (or 'upper') regions of North America (ranging from Alaska to Mid-Oregon), the M geno- 
group viruses are found in the 'middle' regions (Southern Idaho aquaculture region, Columbia River Basin and Washington Coast) and the L genogroup viruses are found in the southern (or 'lower') regions (ranging from Southern Oregon to California) (Garver et al. 2003, Kurath et al. 2003, Breyta et al. 2013). IHNV can infect a range of salmon species but the endemic genogroups exhibit some degree of hostspecific virulence, where strains from the $\mathrm{U}, \mathrm{M}$ and $\mathrm{L}$ genogroups exhibit the highest virulence to $O$. nerka (sockeye salmon and kokanee), O. mykiss (steelhead and rainbow trout), and O. tshawytscha (Chinook salmon), respectively (Garver et al. 2006, Bendorf et al. 2007, Kelley et al. 2007, Peñaranda et al. 2009, Purcell et al. 2009, Breyta et al. 2013). However, this host-specific virulence is not observed in all salmonids; for instance, virulence in Atlantic salmon does not correlate with specific IHNV genogroups, probably due to a historic lack of exposure and subsequent selection (Kurath et al. 2014).

Coastal streams in Washington State, USA, are home to 7 species of Pacific salmonids: Chinook salmon, sockeye salmon, coho salmon $O$. kisutch, chum salmon O. keta, pink salmon O. gorbuscha, steelhead trout, and cutthroat trout $O$. clarkii trout (Gustafson et al. 2007). Prior to 2007, most strains of IHNV detected in the coastal WA region were from the $\mathrm{U}$ genogroup, which displays higher virulence in sockeye salmon (Breyta et al. 2013). However, between 2007 and 2011, there were several epidemics in juvenile steelhead trout, caused by strains from the MD subgroup of the $\mathrm{M}$ genogroup. This genotype was common in the Columbia River Basin but had only been detected once in a Washington coastal population (disease epidemic in juvenile steelhead trout, 1997) (Breyta et al. 2013). The 2007 to 2011 emergence of IHNV did not affect all the coastal streams equally in Washington State, and was not fully explained by the security of hatchery water supplies or by a higher virulence of the emergent strains (Breyta et al. 2014). This variation across streams led to the hypothesis that population-specific host resistance may be one factor influencing the pattern of IHNV emergence. To test this hypothesis, Breyta et al. (2014) evaluated resistance to IHNV in 2 hatchery populations, Quinault National Fish Hatchery (QNFH) steelhead and Lake Quinault Tribal Hatchery steelhead (LQ), which differed in the level of juvenile disease suffered during the emergence event. The 2 populations were founded from the same ancestral population endemic to the Washington coast, Quinault winter steelhead, about $40 \mathrm{yr}$ ago (Breyta et al. 2014). Controlled laboratory IHNV challenge studies demonstrated that the 2 populations exhibited differences in mortality when exposed to a representative MD IHNV strain, with the LQ population being more susceptible to IHNV than the QNFH population.

In the present study, we used a classical quantitative genetic approach to determine whether there is a genetic basis underlying IHNV resistance in the QNFH steelhead trout population, and to determine whether the population has the potential for further adaptation to the pathogen. Logistical constraints of our facility required that we could only assess one population in depth. We chose to focus on the QNFH population because this population showed a higher degree of resistance to IHNV, a trait of interest for conservation. Moreover, this population is maintained for conservation purposes and it was the progenitor population of the LQ population. In the long term, we are interested in characterizing the evolution of disease resistance as a fitness trait in natural populations or in hatchery populations maintained for enhancement or conservation purposes.

The aim of the present study was to determine the proportion of the phenotypic variance that was due to additive genetic variation in pathogen resistance in the QNFH steelhead trout population described by Breyta et al. (2014) and to evaluate whether the population could respond to selection caused by this pathogen. To this end, we estimated the heritability of 2 traits, mortality and days to death, which are measures of resistance to IHNV following exposure to the pathogen. Narrow-sense heritability provides information on the amount of additive variance present in a population, which reflects the potential of the population to adapt to environmental change. Greater genetic variation might facilitate host adaptation to pathogen resistance (Spielman et al. 2004).

\section{MATERIALS AND METHODS}

All animal experiments were approved by the University of Washington Institutional Animal Use and Care Committee (protocol 3042-15). To create experimental crosses with known family structure, gametes were collected from mature adult steelhead trout returning to QNFH (US Fish and Wildlife Service, Humptulips, WA). The absence of viruses in the parents was verified by collecting ovarian fluid and kidney tissues (both males and females), which were subsequently inoculated onto epithelioma papulosum cyprini (EPC) cells (Fijan et al. 1983) using standard virological methods (USFWS \& AFS-FHS 2014). 
All samples tested negative for viruses. The eggs were fertilized by mating each male to 2 females and each female to 2 males in a circular mating design (Kimura \& Crow 1963). This design resulted in both paternal and maternal half-sib families and allowed the partitioning of the genetic variance while permitting independent tests for parental, specifically maternal, effects. A total of 39 sires and 39 dams were used to create 78 families. All families were reared in separate tanks. Of these, 56 families, representing 27 maternal and 23 paternal half-sib families from 29 females and 33 males (see Table S1 in the Supplement at www.int-res.com/articles/suppl/ d117p077_supp.pdf), comprised more than 100 individuals and were kept for subsequent challenges.

Challenges were conducted by waterborne exposure to the IHNV strain Qts07 (type mG110M from the $\mathrm{M}$ genogroup) isolated from a diseased steelhead trout collected in 2007 from the Queets River, WA (Breyta et al. 2013). The virus was propagated in EPC cells at $15^{\circ} \mathrm{C}$, quantified by plaque assay (Batts \& Winton 1989), and stored at $-80^{\circ} \mathrm{C}$ until used. Challenges were conducted using the method described by Garver et al. (2006). The fish used were 3 mo post ponding and the mean weight was $1.2 \mathrm{~g}$. Briefly, 48 fish from each family were divided into 2 replicate tanks containing 11 of static water with aeration and exposed to $2 \times 10^{5}$ plaque-forming units (PFU) $\mathrm{ml}^{-1}$ IHNV, the dose calculated to be lethal to $40 \%$ of the population in a preliminary experiment that used a pool sample of the population. After $1 \mathrm{~h}$, the water flow was resumed and tanks were monitored daily for $21 \mathrm{~d}$. At the end of the $21 \mathrm{~d}$ challenge, survivors were euthanized with an overdose of buffered MS222 (tricaine methanesulfonate). In addition, 12 individuals per family were mock exposed to medium only and held in the same conditions as the exposed individuals. These individuals were used as a control but not considered in the subsequent analysis. For all individuals in the study, we recorded 'mortality' and 'fork length'. Mortality corresponded to the status of an individual at the end of the $21 \mathrm{~d}$ challenge (mortality or survivor). Fork length was measured for each individual at the time of death. During the challenge, the fish were fed a maintenance diet. Therefore, we assumed that growth was not significant. Additionally, the trait 'days to death' was recorded for individuals that died on a particular day following exposure to the virus. We estimated 2 traits related to IHNV resistance ('mortality' and 'days to death') and evaluated the phenotypic and genotypic association between size and IHNV resistance. To verify that mortality was caused by IHNV, 1 to 4 mortalities per
IHNV-exposed tank and all mock control mortalities were stored at $-80^{\circ} \mathrm{C}$ and presence or absence of the virus was determined by cell culture (Batts \& Winton 1989).

Narrow-sense heritability $\left(h^{2}\right)$ corresponds to the proportion of the phenotypic variance $\left(V_{\mathrm{P}}\right)$ that is explained by the additive variance $\left(V_{\mathrm{A}}\right)$ or the variance of breeding values. The animal model can be used to estimate these variance components (Wilson et al. 2010) in the context of complex pedigrees. This model is a particular form of generalized linear mixed effect model that estimates the breeding value of an individual $\left(a_{i}\right)$, the relative genetic merit of an individual, and subsequently treats it as a random effect (Wilson et al. 2010). We used the 'MCMCglmm' package (Hadfield \& Nakagawa 2010) in R that uses Bayesian inference to fit the animal model, as it is appropriate for Gaussian and non-Gaussian distributions. We estimated variance components and $h^{2}$ for 2 traits independently: mortality and days to death (DTD). We investigated whether there was a tank placement effect, fish length effect or maternal effect on the estimation of the variance components by adding these parameters (tank, length, dam) as random effects to the model. Fork length was included as a random effect rather than a fixed effect since we were interested in knowing the proportion of phenotypic variation attributable to the factor length, rather than the effect of each $y_{i j k l}+$ length value. The full model was $y_{i j k l}=\mu+a_{i}+t_{j}+l_{k}+d_{l}+$ $e_{i j k l}$ where $y_{i j k l}$ is the phenotype observed for individual $i$ (mortality or DTD), $\mu$ is the population mean, $a_{i}$ is the breeding value for individual $i, t_{j}$ is the tank effect, $l_{k}$ is the length effect, $d_{l}$ is the dam effect, and $e_{i j k l}$ is the residual term. Mortality was analyzed as a binary trait (de Villemereuil 2012), and we specified a chi-square distribution for the prior on this trait. We used an inverse Wishart distribution for the prior on DTD and the trait was treated as a continuous trait (Hadfield 2010, de Villemereuil 2012). Uninformative inverse gamma distribution priors were used for all the random effects (de Villemereuil 2012). The Markov chains were run with 3000000 to 8000000 iterations, 30000 to 80000 burn-in length, and thinning every 300 to 8000 iterations. Independence and convergence were checked visually and with the function autocorr.diag implemented in 'MCMCglmm'.

Phenotypic resistance to pathogens, including IHNV, increases with age (e.g. Lapatra et al. 1990, Bergmann et al. 2003, Becker et al. 2005, Ryce et al. 2005). However, it is unclear whether there is a relationship between fish length at a specific age and 
IHNV resistance. Overturf et al. (2010) examined the phenotypic correlation between size and resistance to IHNV in rainbow trout and only found a positive correlation for older fish (213 d post-fertilization, $224.7 \mathrm{~g}$ ), but not for younger fish. Additionally, Barroso et al. (2008) determined that the 2 traits were genetically independent in rainbow $\times$ Yellowstone cutthroat trout crosses. To investigate if resistance to IHNV and length are correlated in this study, we estimated the phenotypic correlation $\left(r_{\mathrm{P}}\right)$ between fish length and mortality or DTD and their p-values using the rcorr function in the Hmisc package in R. We then compared the phenotypic correlations to the genetic correlations $\left(r_{\mathrm{G}}\right)$ estimated using a multi-trait model (mortality and length or DTD and length) in 'MCMCglmm'. If 2 traits are controlled by the same genes, or by genes physically linked with each other, the genetic correlation between the 2 traits should be significant. The genetic correlation between mortality and DTD could not be estimated as fish that were alive at the end of the challenge did not have a value for the trait DTD.

To determine whether the differences in mortality between populations as observed by Breyta et al. (2014) were present in our year class, we also performed a comparative experiment in the same environment, by challenging individuals from the LQ population using a similar approach to Breyta et al. (2014). We also performed reciprocal crosses between the LQ and QNFH (hereafter referred to as hybrid crosses) for another independent study and these families were also challenged with IHNV. A total of 10 males and 10 females, and 5 males and 5 females contributed to the hybrid crosses and LQ crosses, respectively. Both groups were challenged simultaneously, but independently from the QNFH population described earlier, because the LQ and hybrid crosses were created later. We aimed to keep the age and weight of the fish constant across challenges. The fish were $3.5 \mathrm{mo}$ post ponding and the mean weights of the hybrid and LQ fish were $1.5 \mathrm{~g}$ and $0.9 \mathrm{~g}$, respectively, at the time of the challenge. The LQ and hybrid crosses were not included in the heritability estimates, because the family structure relevant to these analyses was not created, and only cumulative percent mortality was analyzed and compared to that of the QNFH crosses.

\section{RESULTS AND DISCUSSION}

A total of 2687 QNFH fish were challenged with IHNV in this study; an additional 645 QNFH fish were mock challenged. Twenty-six (4\%) mock individuals died during the challenges, but their death appeared unrelated to IHNV as they tested negative for the virus by cell culture. In contrast, the virus was identified in at least one dead fish in every tank exposed to the virus. The cumulative percent mortality $(\mathrm{CPM})$ per family was $52 \% \pm 18$, ranging from 23 to $92 \%$ mortality per family (Fig. 1). The average DTD was 12.78 and had very limited variation (standard deviation: $1.22 \mathrm{~d}$ ).

Significant heritability for mortality indicated both a genetic basis for resistance to IHNV and moderate genetic variation for resistance in this population. Heritability estimates for mortality at $21 \mathrm{~d}$ was 0.377 (95\% confidence interval: $0.226-0.550$ ) and DTD was 0.093 (95\% confidence interval: 0.018-0.203). For each trait, the tank and maternal effects were limited, each representing less than $0.1 \%$ of the variation observed for both traits, whereas there was a length effect (see Figs. S1 \& S2 in the Supplement at www.int-res.com/articles/suppl/d117p077_supp.pdf). The lower heritability value for DTD is likely to be explained by the fact that there was very little phenotypic variance in that trait, but could equally be explained by the fact that there is little genetic variation underlying this trait. Although heritability values are population-specific, the heritability estimate for mortality in this study is in the range of that estimated in other systems: 0.05 to 0.51 for farmed rainbow trout (Yamamoto et al. 1991) or 0.27 to 0.38 for sockeye salmon (McIntyre \& Amend 1978).
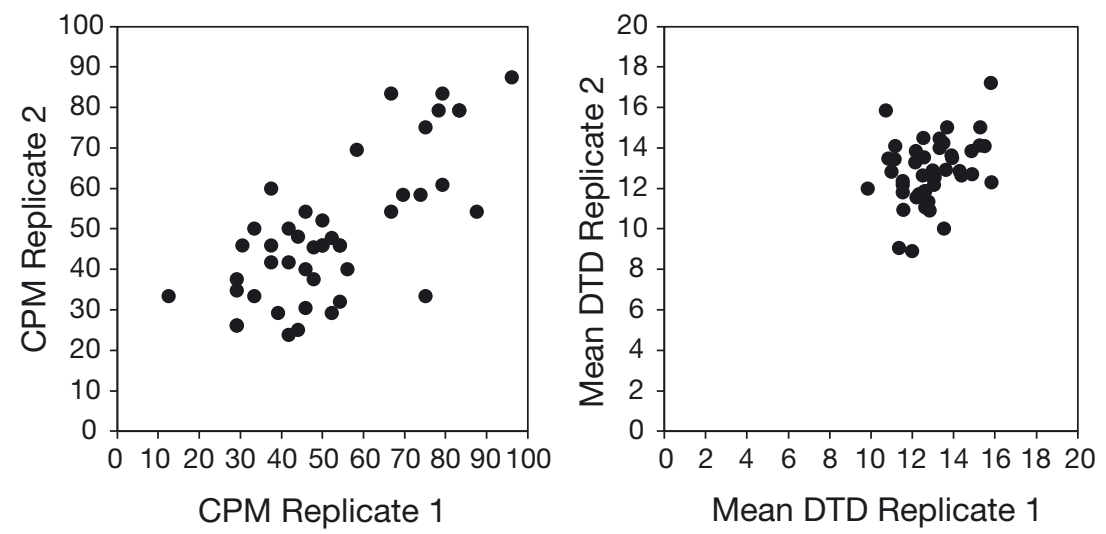

Fig. 1. Relationship between replicate tanks for cumulative percent mortality (CPM) and mean day to death (DTD) for each steelhead trout Oncorhynchus mykiss family following batch exposure to infectious hematopoietic necrosis virus. For each family, the 2 replicate tanks are represented on the $x$ - and $y$-axes 
We observed both phenotypic and genotypic correlations between size at a specific age and susceptibility to the virus. Phenotypic correlations between mortality, DTD and fork length were all significant (Table 1). However, the only significant genetic correlation was between DTD and fork length, and this correlation was positive, indicating that smaller susceptible fish died sooner than larger susceptible fish. This result would suggest that some genes might be involved in both resistance and growth, or that some genes underlying these 2 traits are in linkage disequilibrium. This aspect is particularly interesting as selection on size is a common voluntary or involuntary practice in aquaculture, and selection for larger fish may cause a slight delay in the time to death of the susceptible individuals following exposure to IHNV, potentially allowing the immune system to respond to the pathogen. However, it is important to note that there was little genetic variation underlying DTD in the QNFH steelhead population; therefore, selection for larger fish is likely to have limited effect on the overall susceptibility to IHNV in this population.

We were able to confirm that the difference in susceptibility between the 2 populations, QNFH and LQ, was still evident in the year class we examined. Although the QNFH fish were challenged separately from the LQ and hybrid populations, and a batch challenge effect cannot be ruled out, the CPM of the LQ population $(67 \% \pm 13)$ was higher than that of the QNFH population (Fig. 2), which is similar to the observations of Breyta et al. (2014). Interestingly, the CPM of the hybrid population $(27 \% \pm 13)$ was lower

Table 1. Phenotypic and genetic correlations between mortality, days to death (DTD) and fork length, and heritability estimates for steelhead trout Oncorhynchus mykiss families exposed to infectious hematopoietic necrosis virus. Phenotypic correlations are represented below the diagonal, genotypic correlations are represented above the diagonal, and $95 \%$ confidence intervals are indicated in parentheses. Significant correlations are represented in bold. Phenotypic correlation between mortality and DTD was calculated at the family level because all individuals with a DTD measure were susceptible to the virus. Heritability estimates for mortality and DTD are designated in italics on the diagonal with $95 \%$ confidence intervals

\begin{tabular}{|l|c|c|c|}
\hline & Mortality & DTD & Length \\
\hline Mortality & $\begin{array}{c}0.377 \\
(0.226-0.550)\end{array}$ & NA & $\begin{array}{c}0.012 \\
(-0.071-0.053)\end{array}$ \\
\hline DTD & $\begin{array}{c}\mathbf{- 0 . 2 5} \\
(\mathbf{p = 0 . 0 0 8 )}\end{array}$ & $\begin{array}{c}0.093 \\
(0.018-0.203)\end{array}$ & $\begin{array}{c}\mathbf{0 . 4 7 0} \\
0.080-0.713)\end{array}$ \\
\hline Length & $\begin{array}{c}\mathbf{- 0 . 1 9} \\
(\mathbf{p}<\mathbf{0 . 0 0 1})\end{array}$ & $\begin{array}{c}\mathbf{0 . 3 8} \\
(\mathbf{p}<\mathbf{0 . 0 0 1 )}\end{array}$ & - \\
\hline
\end{tabular}

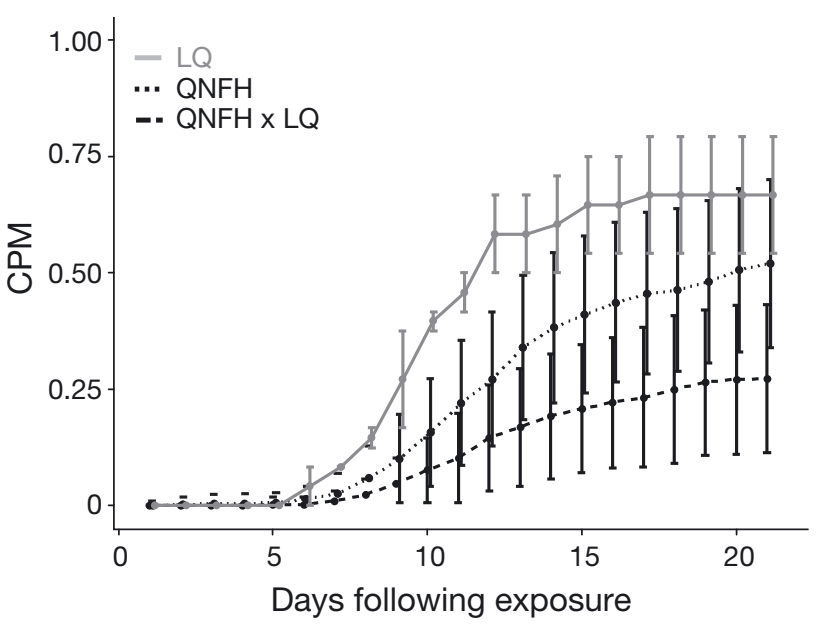

Fig. 2. Cumulative percent mortality (CPM) following batch exposure to infectious hematopoietic necrosis virus for 3 populations of steelhead trout Oncorhynchus mykiss (Lake Quinault - LQ, Quinault National Fish hatchery - QNFH, and hybrids $-\mathrm{QNFH} \times \mathrm{LQ}$ )

than both parental populations, indicating increased resistance among the hybrid crosses. This result could be explained by heterosis (hybrid vigor). However, this hypothesis could not be formally tested, as such a study would require multi-generational data (McClelland \& Naish 2007). Nevertheless, this suggests that the genetic basis for resistance to IHNV might be complex and should be examined further.

The results of this study show that there is a genetic component for host resistance to IHNV and that there is potential for the QNFH steelhead trout population to adapt to this pathogen. Estimates of heritability obtained for this system cannot directly be used to predict evolutionary change in other populations (Carlson \& Seamons 2008). However, along with estimates from previous studies (McIntyre \& Amend 1978, Yamamoto et al. 1991), these results provide a range of possible values that might be observable in other populations. If genetic variation is reduced in some populations, either through natural evolutionary processes, or through harvest activities or hatchery practices such as inbreeding, this reduction could affect their ability to adapt to the pathogen. Such reduction of genetic variation, as well as the presence or absence of resistant alleles, could therefore be partly responsible for heterogeneous host susceptibility. It would therefore be invaluable to identify genetic markers linked to IHNV resistance in order to better understand how differences in host susceptibility might affect emergence and transmission of IHNV across the landscape. Although previous studies have identified polymorphisms and markers linked to IHNV in salmonids through candidate gene 
approaches (Palti et al. 1999, 2001, Trobridge et al. 2000, Arkush et al. 2002, Miller et al. 2004, Liu et al. 2013), low density quantitative trait loci (QTL) mapping (Khoo et al. 2004, Barroso et al. 2008) and genome-wide association studies (Campbell et al. 2014), new tools available for Oncorhynchus mykiss, including a draft genome (Berthelot et al. 2014) and a 57K single nucleotide polymorphism (SNP) chip (Palti et al. 2015), will facilitate molecular-based studies on a more extensive portion of the genome.

Acknowledgements. This project is supported by the Agriculture and Food Research Initiative competitive grant no. 2012-67015-19960 of the USDA National Institute of Food and Agriculture. We thank Bill Edwards at the Quinault National Fish Hatchery and Tyler Jurasin at the Lake Quinault hatchery for allowing us to obtain gametes from their facilities. We thank Gael Kurath, Rachel Thompson, Dorothy Chase, Skye Pearman-Gillman and Rachel Breyta for assistance and advice with the challenges and the laboratory work. The use of trade, firm, or corporation names in this publication is for the information and convenience of the reader. Such use does not constitute an official endorsement or approval by the US Government of any product or service to the exclusion of others that may be suitable.

\section{LITERATURE CITED}

Arkush KD, Giese AR, Mendonca HL, McBride AM, Marty GD, Hedrick PW (2002) Resistance to three pathogens in the endangered winter-run chinook salmon (Oncorhynchus tshawytscha): effects of inbreeding and major histocompatibility complex genotypes. Can J Fish Aquat Sci 59:966-975

Barroso RM, Wheeler PA, LaPatra SE, Drew RE, Thorgaard GH (2008) QTL for IHNV resistance and growth identified in a rainbow (Oncorhynchus mykiss) $\times$ Yellowstone cutthroat (Oncorhynchus clarki bouvieri) trout cross. Aquaculture 277:156-163

Batts WN, Winton JR (1989) Enhanced detection of infectious hematopoietic necrosis virus and other fish viruses by pretreatment of cell monolayers with polyethylene glycol. J Aquat Anim Health 1:284-290

Becker JA, Speare DJ, Dohoo IR (2005) Influence of feeding ratio and size on susceptibility to microsporidial gill disease caused by Loma salmonae in rainbow trout, Oncorhynchus mykiss (Walbaum). J Fish Dis 28:173-180

Bendorf CM, Kelley GO, Yun SC, Kurath G, Andree KB, Hedrick RP (2007) Genetic diversity of infectious hematopoietic necrosis virus from Feather River and Lake Oroville, California, and virulence of selected isolates for Chinook salmon and rainbow trout. J Aquat Anim Health 19:254-269

Bergmann SM, Fichtner D, Skall HF, Schlotfeldt HJ, Olesen NJ (2003) Age- and weight-dependent susceptibility of rainbow trout Oncorhynchus mykiss to isolates of infectious haematopoietic necrosis virus (IHNV) of varying virulence. Dis Aquat Org 55:205-210

> Berthelot C, Brunet F, Chalopin D, Juanchich A and others (2014) The rainbow trout genome provides novel insights into evolution after whole-genome duplication in vertebrates. Nat Commun 5:3657

Breyta R, Jones A, Stewart B, Brunson R and others (2013) Emergence of MD type infectious hematopoietic necrosis virus in Washington State coastal steelhead trout. Dis Aquat Org 104:179-195

> Breyta R, Jones A, Kurath G (2014) Differential susceptibility in steelhead trout populations to an emergent MD strain of infectious hematopoietic necrosis virus. Dis Aquat Org 112:17-28

Campbell NR, LaPatra SE, Overturf K, Towner R, Narum SR (2014) Association mapping of disease resistance traits in rainbow trout using restriction site associated DNA sequencing. G3 (Bethesda) 4:2473-2481

Carlson SM, Seamons TR (2008) A review of quantitative genetic components of fitness in salmonids: Implications for adaptation to future change. Evol Appl 1: 222-238

de Villemereuil P (2012) Tutorial: Estimation of a biological trait heritability using the animal model. How to use the MCMCglmm R package http://devillemereuil.legtux. org/wp-content/uploads/2012/12/tuto_en.pdf

Fijan N, Sulimanovic D, Bearzotti M, Muzinic D and others (1983) Some properties of the epithelioma-papulosumcyprini (EPC) cell-line from carp Cyprinus carpio. Ann Inst Pasteur Virol 134:207-220

> Garver KA, Troyer RM, Kurath G (2003) Two distinct phylogenetic clades of infectious hematopoietic necrosis virus overlap within the Columbia River Basin. Dis Aquat Org 55:187-203

> Garver KA, Batts WN, Kurath G (2006) Virulence comparisons of infectious hematopoietic necrosis virus $U$ and $\mathrm{M}$ genogroups in sockeye salmon and rainbow trout. J Aquat Anim Health 18:232-243

Gustafson RG, Waples RS, Myers JM, Weitkamp LA, Bryant GJ, Johnson OW, Hard JJ (2007) Pacific salmon extinctions: quantifying lost and remaining diversity. Conserv Biol 21:1009-1020

Hadfield JD (2010) MCMC methods for multi-response generalized linear mixed model: The MCMCglmm R package. J Stat Softw 33:2-22

Hadfield JD, Nakagawa S (2010) General quantitative genetic methods for comparative biology: phylogenies, taxonomies and multi-trait models for continuous and categorical characters. J Evol Biol 23:494-508

Kelley GO, Bendorf CM, Yun SC, Kurath G, Hedrick RP (2007) Genotypes and phylogeographical relationships of infectious hematopoietic necrosis virus in California, USA. Dis Aquat Org 77:29-40

- Khoo SK, Ozaki A, Nakamura F, Arakawa T and others (2004) Identification of a novel chromosomal region associated with infectious hematopoietic necrosis (IHN) resistance in rainbow trout Oncorhynchus mykiss. Fish Pathol 39:95-101

Kimura M, Crow JF (1963) On the maximum avoidance of inbreeding. Genet Res 4:399-415

Kurath G (2012) Fish novirhabdoviruses In: Dietzgen RG, Kuzmin IV (eds) Rhabdoviruses: molecular taxonomy, evolution, genomics, ecology, host-vector interactions, cytopathology and control. Caister Academic Press, Wymondham, p 89-116

Kurath G, Garver KA, Troyer RM, Emmenegger EJ, EinerJensen K, Anderson ED (2003) Phylogeography of infectious haematopoietic necrosis virus in North America. J Gen Virol 84:803-814 
Kurath G, Winton JR, Dale OB, Purcell MK, Falk K, Busch RA (2014) Atlantic salmon, Salmo salar L., are broadly susceptible to isolates representing the North American genogroups of infectious hematopoietic necrosis virus. J Fish Dis, doi:10.1111/jfd.12323

Lapatra SE, Groberg WJ, Rohovec JS, Fryer JL (1990) Sizerelated susceptibility of salmonids to two strains of infectious hematopoietic necrosis virus. Trans Am Fish Soc 119:25-30

Liu Z, Hu DD, Shao SJ, Huang JQ, Wang JF, Yang J (2013) Polymorphisms in major histocompatibility complex class II alpha genes are associated with resistance to infectious hematopoietic necrosis in rainbow trout, Oncorhynchus mykiss (Walbaum, 1792). J Appl Ichthyol 29:1234-1240

> McClelland EK, Naish KA (2007) What is the fitness outcome of crossing unrelated fish populations? A metaanalysis and an evaluation of future research directions. Conserv Genet 8:397-416

McIntyre JD, Amend DF (1978) Heritability of tolerance for infectious hematopoietic necrosis in sockeye salmon (Oncorhynchus nerka). Trans Am Fish Soc 107: 305-308

Miller KM, Winton JR, Schulze AD, Purcell MK, Ming TJ (2004) Major histocompatibility complex loci are associated with susceptibility of Atlantic salmon to infectious hematopoietic necrosis virus. Environ Biol Fishes 69: 307-316

- Overturf K, LaPatra S, Towner R, Campbell N, Narum S (2010) Relationships between growth and disease resistance in rainbow trout, Oncorhynchus mykiss (Walbaum). J Fish Dis 33:321-329

Palti Y, Parsons JE, Thorgaard GH (1999) Identification of candidate DNA markers associated with IHN virus resistance in backcrosses of rainbow (Oncorhynchus mykiss) and cutthroat trout (O. clarki). Aquaculture 173: 81-94

Palti Y, Nichols KM, Waller KI, Parsons JE, Thorgaard GH (2001) Association between DNA polymorphisms tightly linked to MHC class II genes and IHN virus resistance in backcrosses of rainbow and cutthroat trout. Aquaculture 194:283-289

Editorial responsibility: Mark Crane, Geelong, Victoria, Australia
Palti Y, Gao G, Liu S, Kent MP and others (2015) The development and characterization of a $57 \mathrm{~K}$ single nucleotide polymorphism array for rainbow trout. Mol Ecol Resour 15:662-672

> Peñaranda MMD, Purcell MK, Kurath G (2009) Differential virulence mechanisms of infectious hematopoietic necrosis virus in rainbow trout (Oncorhynchus mykiss) include host entry and virus replication kinetics. J Gen Virol 90: 2172-2182

> Purcell MK, Garver KA, Conway C, Elliott DG, Kurath G (2009) Infectious haematopoietic necrosis virus genogroup-specific virulence mechanisms in sockeye salmon, Oncorhynchus nerka (Walbaum), from Redfish Lake, Idaho. J Fish Dis 32:619-631

> Ryce EKN, Zale AV, MacConnell E, Nelson M (2005) Effects of fish age versus size on the development of whirling disease in rainbow trout. Dis Aquat Org 63:69-76

Spielman D, Brook BW, Briscoe DA, Frankham R (2004) Does inbreeding and loss of genetic diversity decrease disease resistance? Conserv Genet 5:439-448

Trobridge GD, LaPatra SE, Kim CH, Leong JC (2000) Mx mRNA expression and RFLP analysis of rainbow trout Oncorhynchus mykiss genetic crosses selected for susceptibility or resistance to IHNV. Dis Aquat Org 40:1-7

USFWS, AFS-FHS (US Fish and Wildlife Service and American Fisheries Society-Fish Health Section) (2014) Standard procedures for aquatic animal health inspections. In: AFS-FHS. FHS blue book: suggested procedures for the detection and identification of certain finfish and shellfish pathogens, 2014 edn. Accessible at: http:// afsfhs.org/bluebook/bluebook-index.php

Wilson AJ, Réale D, Clements MN, Morrissey MM and others (2010) An ecologist's guide to the animal model. J Anim Ecol 79:13-26

Wolf K (1988) Infectious hematopoietic necrosis virus. In: Anonymous fish viruses and fish viral diseases. Cornell University Press, Ithaca, NY, p 83-114

- Yamamoto S, Sanjyo I, Sato R, Kohara M, Tahara H (1991) Estimation of the heritability for resistance to infectious hematopoietic necrosis in rainbow trout. Bull Jpn Soc Sci Fish 57:1519-1522

Submitted: June 19, 2015; Accepted: September 24, 2015 Proofs received from author(s): October 20, 2015 